\title{
YIELD AND QUALITY OF SULTANI GRAPES (VITIS VINIFERA L.) TREATED WITH 28-HOMOBRASSINOLIDE AND GIBBERELLIC ACID
}

\author{
IşÇı, B. \\ Department of Horticulture, Faculty of Agriculture, Ege University, Bornova/İzmir, Turkey \\ (ORCID ID: 0000-0002-6542-0271) \\ e-mail: burcak.isci@ege.edu.tr
}

(Received $10^{\text {th }}$ May 2019; accepted $16^{\text {th }} \mathrm{Jul} 2019$ )

\begin{abstract}
In this study, the effects of gibberellic acid $\left(\mathrm{GA}_{3}\right)$ and brassinosteroid (BRs) applications on the yield and berry quality of Sultani grapes were determined during the 2017-2018 period. 28homobrassinolide ( $\mathrm{Hbl}$ ) solutions with concentrations $4 \mathrm{ppm}(\mathrm{Hbl}-4)$ and $8 \mathrm{ppm}(\mathrm{Hbl}-8)$ were sprayapplied at veraison. Three $\mathrm{GA}_{3}$ concentrations were implemented by spraying method. The applications times were as follows; Application 1: $10 \mathrm{ppm}$, clusters 5-10 cm in length at pre-bloom stage (first week of May), Application 2: $15 \mathrm{ppm}$ at 45-50\% flowering (mid-June), and Application 3: $20 \mathrm{ppm}$ with 3-5 mm berry diameter stage. $\mathrm{GA}_{3}$ and $\mathrm{BRs}$ on yield components, some quality characteristics relating to clusters and berries (weight, breadth and length, etc.), color of bunches, total phenol content and antioxidant activity were investigated. Results showed that the effects differed, and they were not consistent on all the variables. Effects of the $\mathrm{HBl}$ treatments on yield were not as high as $\mathrm{GA}_{3}$ but there were some positive improvements. Hbl was found to be influential on increasing cluster breadth. Berries were harder with the hormone applications. Quality characteristics were more influenced by the seasons rather than the hormones. Color and total anthocyanin contents were better with the hormones. Fructose content indicated a significant increase with the Hbl-4 application. 28-homobrassinolide might carry some potentially useful effects on improving yield, not to the extent of $\mathrm{GA}_{3}$, and also on color along with increasing sweetness during the production of 'Sultani' grapes.
\end{abstract}

Keywords: Vitis vinifera, Sultani, berry, hormone, gibberellic acid $\left(G A_{3}\right)$, brassinosteroid

\section{Introduction}

In Turkey, only about 50-60 grape cultivars are economically cultivated despite their vast variety (about 1200). Seedless table grape production constitutes about $37 \%$ of all production. Sultani (aka 'Thompson Seedless'), originated from the Aegean region of Turkey, since it is the most valuable raisin and table grape variety in the world. Its berries are green-yellow in color, seedless and small, with ellipsoid shaped berries, and the bunches are very large in size with long cylindrical body with wings on both sides (İşçi and Altındişli, 2015).

Applications of growth regulators such as gibberellins, ethylene or auxin in grape growing aim to improve fruit yield and quality. Especially gibberellic acid is the most effective growth regulator in improving bunch compactness, berry characters as well as yield and quality of berries. Gibberellic acid is mostly commercially used in seedless varieties to increase yield of grapes depending on its concentration and the time of application (İşçi and Gökbayrak, 2015; Reynolds et al., 2016; Ghorbani et al., 2017).

Brassinosteroids promote a dual response of cell division and cell elongation resulting in both enhancement and acceleration of the overall growth of the plants (Bartwal et al., 2013; Ali, 2017; Chai, 2012). They show growth regulatory effects in plants similar to those of endogenous plant hormones, auxins and gibberellins. In carrot, application of 24-epibrassinolide resulted in longer plants with increased vegetation weight (Que et al., 2017). Chai et al. (2013) determined that keeping brassinosteroids 
from expression resulted in delayed color development in strawberries. It was shown that the application of brassinosteroid to grape berries evidently enhanced skin coloration and the final sugar level of the flesh, and significantly promoted ripening (Mitchell et al., 1970; Vardhini and Rao, 2002; Symons et al., 2006).

The objective of this study was to determine and compare the effects of gibberellic acid $\left(\mathrm{GA}_{3}\right)$ and 28-homobrassinolide applied at different phenological stages on quantity and quality of the 'Sultani' vines.

\section{Materials and methods}

\section{Plant material}

Vitis vinifera L. 'Sultani', a seedless grape, was grafted on 41B rootstock in 2005. Implementations were carried out at the experimental vineyard located in Bornova, İzmir. The vineyard is on sandy and silt soil $2.0 \times 3.0 \mathrm{~m}$ spacing. Each vine carried approximately 20 grape clusters. Guyot-trained vines with four canes carrying 11-12 buds were drip irrigated. All viticulture practices were performed according to standard vineyard practices. During winters of 2017 and 2018, Bordeaux mix was applied following pruning, and wettable powder sulphur was used when the summer shoots were $10 \mathrm{~cm}$ long. Lateral shoots were accordingly removed in order to facilitate pest management.

Hormone treatments including the control were carried out freshly prepared solutions that contained $0.1 \%$ Tween 20 as the surfactant. Control vines were sprayed with distilled water. There were no other manipulations on the clusters. 28-homobrassinolide (Hbl, 0.1\%; Repar, MD, USA) solutions with concentrations 4 ppm (Hbl-4) and 8 ppm (Hbl-8) were applied at veraison (last week of July) by spraying with a handgun sprayer at a rate of $10 \mathrm{ml} / \mathrm{cluster}$, and the solution was made sure to cover the entire surface area of the berries in each cluster. Three $\mathrm{GA}_{3}$ concentrations were implemented by spraying method. The applications times were as following; 1 . application: $10 \mathrm{ppm}$, clusters 5$10 \mathrm{~cm}$ in length at pre-bloom stage (first week of May), 2. application: $15 \mathrm{ppm}$ at 45 $50 \%$ flowering (mid-June), and 3. application: $20 \mathrm{ppm}$ with $3-5 \mathrm{~mm}$ berry diameter stage (last week of July).

The weather conditions in the two seasons (2017 and 2018, respectively) were as follows: average monthly temperature in year round was $18.2{ }^{\circ} \mathrm{C}$ and $19.2{ }^{\circ} \mathrm{C}$. Mean temperature during the months of vegetation period (April-October) was 24.2 and $24.3^{\circ} \mathrm{C}$. Mean total precipitation was $1.78 \mathrm{~mm}$ and $1.65 \mathrm{~mm}$, during which the vegetation period it was recorded as 0.64 and $0.93 \mathrm{~mm}$. Average humidity was $60.6 \%$ and $64.3 \%$ throughout the seasons. The relative humidity during the vegetation period in 2018 was $4.2 \%$ higher compared to that in 2017.

The vines were monitored and harvested when the control vines reached $16^{\circ}$ Brix. Yield components (yield per vine and per hectare) were recorded and some quality characteristics relating to clusters and berries (weight, breadth and length, etc.) were determined under lab conditions. Tensile strength of the pedicel (Newton, N) was measured with a penetrometer (Somyftec, France) on 50 berries taken from the clusters. The external berry color was measured at the equatorial area of each side of 50 berries using a colorimeter (CR-300, Minolta Co, Osaka, Japan), average scores were recorded in terms of CIE-L* $\mathrm{a}^{*} \mathrm{~b}^{*}$ values. The colorimeter had an $8 \mathrm{~mm}$ diameter viewing area and was calibrated with a white tile $\left(\mathrm{L}^{*}=97.26, \mathrm{a}^{*}=+0.13, \mathrm{~b}^{*}=+1.71\right)$. From these data, the Color Index of Red Grapes (CIRG) (Carreño et al., 1996) was calculated as: 
CIRG $=\left(180-\mathrm{h}^{\circ}\right) /\left(\mathrm{C}^{*}+\mathrm{L}^{*}\right)$. Based on this index, the berries were classified into five categories: green-yellow (CIRG < 2); pink $(2<\mathrm{CIRG}<4)$; red $(4<\mathrm{CIRG}<5)$; dark red $(5<$ CIRG $<6)$; and blue-black $($ CIRG $>6)$.

The total soluble solids ( ${ }^{\circ}$ Brix) content in the juice was determined with a digital refractometer (PR-1, Atago, Tokyo, Japan) and expressed as percentage. Titratable acidity was measured by titration with $0.1 \mathrm{~N} \mathrm{NaOH}$ to $\mathrm{pH} 8.1$, and the results were expressed as g tartaric acid $100 \mathrm{~mL}-1$ fruit juice. Sugar composition of grape (fructose and glucose) was determined with HPLC (Thermo Dionex Ultimate 3000) according Camara et al. (1996) only in year 2017. Total phenol content and extraction for antioxidant activity was measured by Thaiponga et al. (2006).

\section{Statistical analysis}

The trial was completely randomized with three replicates in each treatment. Each replicate had four vines. A total of 12 vines was used for each application. The mean data collected relating to different parameters of 'Sultani' grapes were statistically analyzed by Minitab ${ }^{\circledR} 16.1 .1$ statistical software. The differences between the significant means were determined with the Tukey's test $(\mathrm{p} \leq 0.05)$.

\section{Results and discussion}

Yield components of the cultivar were not affected by the treatments (Table 1). However, the seasonal variations exhibited significant differences and always in the second year that decreases were observed. The weather data indicated that although mean values of temperature, humidity and precipitation all year round were not quite apart, the values during the vegetation period showed that the second period was hotter, more humid and had more rain. This might have caused the yield to be lower. Interestingly, in the first year of hormone applications, $\mathrm{GA}_{3}$ had always the highest values, followed by mostly the control group. In second year of the experiment, on the other hand, it was the control group that had the highest cluster and vine yield. One stipulation on this observation could be that hormone treated vines might be more prone to the adverse effects of the weather conditions or that they might exert some negative effects on bud fruitfulness. Vergara et al. (2018) also stated that exogenous applications of brassinosteroids at veraison did not improve yield. Senthilkumar et al. (2018) investigated preharvest application of $\mathrm{GA}_{3}$ and brassinosteroid together and found that they provided best vine yield and highest cluster weight. Champa et al. (2015) showed that $0.5 \mathrm{ppm}$ brassinosteroid at pea stage and veraison significantly increased bunch weight in 'Flame Seedless'. Baneh et al. (2017) reported positive effects of $\mathrm{GA}_{3}$ on increasing yield of Iranian seeded grape cultivars. In their study involving application of a $\mathrm{GA}_{3}$ based growth regulator, Nicolaescu et al. (2015) indicated its promoting activity on cluster productivity in 'Beauty Seedless' cultivar. Reynolds et al. (2016) also reported effects of $\mathrm{GA}_{3}$ on increasing yield as positive and negative dependent on the cultivars. Ghorbani et al. (2017) stated that effects of 24-epibrassinolide on yield of 'Thompson Seedless'vines were mainly dependent on the time of the applications, such that after bloom it tended to provide the highest yield, but it gave the lowest yield when applied at budbreak.

Cluster characteristics, except for the cluster length, did not change with the hormone applications (Table 2). The clusters were wider than they were longer, showing that 28homobrassinolide was as effective as $\mathrm{GA}_{3}$. Fresh and dry weight of the rachis were 
higher in the first year. Cluster length showed a significant increase in the second year. Although Haubrick and Assmann (2006) stated promoting effect of brassinosteroids on stem elongation, this effect was not observed in this study. This might be due to circumstances of the trial conducted. The increase was seen in all the clusters in the experiment. Champa et al. (2015) stated in their study with double application of brassinosteroid that cluster size significantly increased in 'Flame Seedless'.

The hormone treatments generally caused no significant differences in the characteristics of berries (Table 3). Berry breadth, berry weight and tensile strength of the pedicel differed between the seasons, being higher in the first season. Berry firmness was affected by the hormone application. Clear difference was observed between $\mathrm{GA}_{3}$ and the Hbl-4/control groups. It seems that $\mathrm{H} 8$ was also capable of increasing berry firmness as $\mathrm{GA}_{3}$ did. This might be the result of brassinosteroids, keeping the pectins in the cell walls from solubilization and/or depolymerization which lead to pulp softening (Villareal et al., 2008). Suehiro et al. (2018) reported enlarging effect of $\mathrm{GA}_{3}$ in 'Shine Muscat' grapes. There are many reports on the effects of GA and CK on berry enlargement throughout the developmental stage (Peppi and Fidelibus, 2008; Zoffoli et al., 2009; Acheampong et al., 2015). In Flame Seedless (Champa et al., 2015) berry weight and berry size showed an increase after brassinosteroid applications at pea stage and veraison. $\mathrm{GA}_{3}$ treated vines of 'Thompson Seedless' produced heavier berries with greater size compared to the control vines (Koukourikou et al., 2015). 'Skookum Seedless' berries increased their firmness following application of $\mathrm{GA}_{3}$ (Reynolds et al., 2016).

Quality of the 'Sultani' berries were not affected by the treatment (Table 4), but they showed a significant increase in the second season compared to the first season. Soluble solids content between $\mathrm{GA}_{3}$ and Hbl-4 treatment was comparably high in 2016, and a balance was observed in all the applications in 2017. Total acidity exhibited a slight increase in the second season. Maturity index was under the influence of the hormones. Hbl-4 resulted in the highest index value in both seasons. The others showed a minor decrease in the second season. Our findings were in consistent with those of Vergara et al. (2018) in 'Red Globe' and in contrast with those of Ashgari and Rezaei-Rad (2018) in 'Thompson Seedless". Reynolds et al. (2016) also showed that response of berry quality characteristics was cultivar specific. İşçi and Gökbayrak (2015) indicated no effects of homobrassinolide applied at anthesis on Brix and $\mathrm{pH}$ of 'Alphonse Lavallee', but they showed that seasonal effects were clear on total acidity.

Color of the berries were interactively affected by the treatments and the season (Table 5). Brightness $\left(\mathrm{L}^{*}\right)$ was higher and generally the same in the second season. Yellowness $\left(b^{*}\right)$ was generally similar between the seasons, except for the Hbl-8 treatment. As was with the brightness, $b^{*}$ was higher in the treated berries compared to the control berries. Redness $\left(\mathrm{a}^{*}\right)$ stayed at similar levels among the hormone applications, but significantly increased between the seasons. CIRG value (Carreño et al., 1996) of the grapes showed that the 'Sultani' berries fall within the class of greenyellow. It did not change with the applications, but seasonal differences were found significant even though the class they belonged to be the same. In agreement with our findings, Vergara et al. (2018) stated that brassinosteroid analogs applied to Red Globe berries at veraison resulted in better coloration. However, the response here was also dependent on the seasonal effects.

Biochemical aspects of the berries treated with various hormones indicated that hormones resulted with significant contributions to the contents of total anthocyanin and 
total phenolics (Table 6). TAC increased with the hormones. TPC on the other hand responded differently to the type of the hormones. $\mathrm{GA}_{3}$ treated berries had the highest TPC, but 28-homobrassinolid comparably lowered it. Ma et al. (2012), in agreement, showed that 24-epibrassinolide increased phenolic contents in grapes. Since the responses of TAC and TPC were similar to the treatments, it can be assumed that the phenolics contents in the 'Sultani' berries might be mainly related to anthocyanin accumulation as also stated by (Xi et al., 2013). Fructose content of the berries showed a significant increase with Hbl-4 treatment. Glucose accumulated more with the hormones than the control group. In a similar study Asghari and Rezaei-Rad (2018) indicated that three times applied 24-epibrassinolide made a significant contribution to the total anthocyanin contents of 'Thompson Seedless' table grapes. Vergara et al. (2018) also showed that brassinosteroid analogs improved the anthocyanin content of 'Red Globe' grapes. Application of $0.6 \mathrm{ppm}$ at veraison resulted in highest total phenolics and total anthocyanin contents in 'Thompson Seedless' berries (Ghorbani et al., 2017).

Table 1. Yield components of 'Sultani' vines at harvest for growing seasons of 2017 and $2018($ mean $\pm S D)$

\begin{tabular}{|c|c|c|c|c|c|c|}
\hline \multirow[b]{2}{*}{ Hormones } & \multicolumn{2}{|c|}{$\begin{array}{c}\text { Cluster weight } \\
\text { (g) }\end{array}$} & \multicolumn{2}{|c|}{$\begin{array}{c}\text { Yield per vine } \\
(\mathbf{k g})\end{array}$} & \multicolumn{2}{|c|}{$\begin{array}{c}\text { Yield per ha } \\
\text { (ton) }\end{array}$} \\
\hline & 2017 & 2018 & 2017 & 2018 & 2017 & 2018 \\
\hline $\begin{array}{c}\mathrm{GA}_{3} \\
(10-15-20 \mathrm{ppm}) \\
\end{array}$ & $762.58 \pm 181.2$ & $383.93 \pm 57.0$ & $15.23 \pm 3.62$ & $7.68 \pm 1.14$ & $25.41 \pm 6.03$ & $12.79 \pm 1.90$ \\
\hline $\mathrm{Hbl} 4$ ppm & $608.72 \pm 63.2$ & $326.99 \pm 155.6$ & $12.17 \pm 1.26$ & $6.54 \pm 3.11$ & $20.29 \pm 2.11$ & $10.90 \pm 5.18$ \\
\hline Hbl 8 ppm & $548.33 \pm 72.1$ & $352.77 \pm 124,2$ & $10.97 \pm 1.44$ & $7.05 \pm 2.48$ & $18.27 \pm 2.40$ & $11.75 \pm 4.14$ \\
\hline Control & $601.14 \pm 8.7$ & $490.92 \pm 46.9$ & $12.02 \pm 0.97$ & $9.82 \pm 0.94$ & $20.03 \pm 3.30$ & $16.35 \pm 1.57$ \\
\hline Mean & $630.19 \pm 128 \mathrm{~A}^{*}$ & $388.65 \pm 111.5 \mathrm{~B}$ & $12.60 \pm 2.56 \mathrm{~A}$ & $7.77 \pm 2.23 \mathrm{~B}$ & $21.00 \pm 4.26 \mathrm{~A}$ & $12.95 \pm 3.72 \mathrm{~B}$ \\
\hline$p$ value & \multicolumn{2}{|c|}{0.000} & \multicolumn{2}{|c|}{0.000} & \multicolumn{2}{|c|}{0.000} \\
\hline
\end{tabular}

*Uppercase letters in the rows indicate the significant differences between the seasons

Table 2. Effects of hormone treatments on cluster traits of 'Sultani' grapes (mean $\pm S D$ )

\begin{tabular}{c|c|c|c|c|c|c|c|c}
\hline & \multicolumn{2}{|c|}{ Cluster breadth $(\mathbf{c m})$} & \multicolumn{3}{c|}{ Cluster length $(\mathbf{c m})$} & \multicolumn{2}{c}{$\begin{array}{c}\text { Rachis fresh weight } \\
(\mathbf{g})\end{array}$} & \multicolumn{2}{c}{$\begin{array}{c}\text { Rachis dry weight } \\
\text { (g) }\end{array}$} \\
\hline Hormones & 2017 & 2018 & 2017 & 2018 & 2017 & 2018 & 2017 & 2018 \\
\hline $\begin{array}{c}\mathrm{GA}_{3} \\
(10-15-20 \mathrm{ppm})\end{array}$ & $26.50 \pm 2.18$ & $27.22 \pm 3.13$ & $11.67 \pm 1.26$ & $14.92 \pm 1.81$ & $20.56 \pm 2.6$ & $13.43 \pm 3.92$ & $8.99 \pm 0.46$ & $6.08 \pm 0.38$ \\
\hline $\mathrm{Hbl} 4 \mathrm{ppm}$ & $28.35 \pm 3.43$ & $26.53 \pm 3.33$ & $10.33 \pm 2.57$ & $11.78 \pm 1.36$ & $20.42 \pm 1.42$ & $12.67 \pm 1.96$ & $8.42 \pm 1.37$ & $6.32 \pm 0.55$ \\
\hline $\mathrm{Hbl} 8 \mathrm{ppm}$ & $25.17 \pm 3.01$ & $23.90 \pm 2.50$ & $9.50 \pm 3.50$ & $12.20 \pm 0.00$ & $16.58 \pm 5.22$ & $14.90 \pm 7.21$ & $7.08 \pm 1.87$ & $7.35 \pm 1.80$ \\
\hline Control & $27.50 \pm 4.3$ & $26.47 \pm 1.70$ & $9.33 \pm 1.04$ & $12.25 \pm 2.21$ & $22.03 \pm 6.43$ & $23.48 \pm 9.72$ & $9.16 \pm 2.59$ & $9.62 \pm 3.16$ \\
\hline Mean & $26.88 \pm 3.11$ & $26.03 \pm 2.68$ & $10.26 \pm 2.20 \mathrm{~B}$ & $12.78 \pm 2.27 \mathrm{~A}$ & $19.90 \pm 4.27$ & $16.12 \pm 7.12$ & $8.41 \pm 1.72$ & $7.34 \pm 2.15$ \\
\hline$p$ value & \multicolumn{2}{|c|}{$>0.05$} & \multicolumn{3}{|c|}{0.013} & \multicolumn{2}{c|}{$>0.05$} & $>0.05$ \\
\hline
\end{tabular}

*Uppercase letters in the rows indicate the significant differences between the seasons 
Table 3. Effects of hormone treatments on berry traits of 'Sultani' grapes (mean $\pm S D$ )

\begin{tabular}{|c|c|c|c|c|c|c|c|c|c|c|c|}
\hline \multirow[b]{2}{*}{ Hormones } & \multicolumn{2}{|c|}{ Berry breadth $(\mathrm{mm})$} & \multicolumn{2}{|c|}{ Berry length (mm) } & \multicolumn{2}{|c|}{100 berry weight (g) } & \multicolumn{3}{|c|}{$\begin{array}{l}\text { Berry firmness } \\
\text { (N) }\end{array}$} & \multicolumn{2}{|c|}{ Tensile strength (N) } \\
\hline & 2017 & 2018 & 2017 & 2018 & 2017 & 2018 & 2017 & 2018 & Mean & 2017 & 2018 \\
\hline $\begin{array}{c}\mathrm{GA}_{3} \\
(10-15-20 \mathrm{ppm})\end{array}$ & $16.2 \pm 2.44$ & $12.72 \pm 0.08$ & $17.40 \pm 0.72$ & $16.12 \pm 0.73$ & $243.22 \pm 59.2$ & $174.63 \pm 11.90$ & $8.51 \pm 0.72$ & $7.25 \pm 0.73$ & $7.88 \pm 0.95 \mathrm{a}$ & $293.83 \pm 48.66$ & $217.40 \pm 25.63$ \\
\hline $\mathrm{Hbl} 4 \mathrm{ppm}$ & $14.26 \pm 0.77$ & $12.25 \pm 0.60$ & $16.51 \pm 0.84$ & $15.33 \pm 0.40$ & $218.41 \pm 29.66$ & $148.63 \pm 33.48$ & $6.42 \pm 0.84$ & $5.60 \pm 0.40$ & $6.01 \pm 0.74 \mathrm{~b}$ & $246.83 \pm 9.02$ & $211.00 \pm 19.94$ \\
\hline $\mathrm{Hbl} 8 \mathrm{ppm}$ & $13.90 \pm 1.07$ & $12.57 \pm 0.35$ & $16.24 \pm 0.96$ & $16.84 \pm 0.18$ & $201.17 \pm 6.2$ & $186.35 \pm 0.95$ & $6.80 \pm 0.95$ & $7.43 \pm 0.18$ & $7.11 \pm 0.70 \mathrm{ab}$ & $243.17 \pm 22.83$ & $231.10 \pm 24.30$ \\
\hline Control & $13.75 \pm 0.16$ & $12.92 \pm 0.77$ & $16.45 \pm 0.25$ & $18.19 \pm 0.86$ & $203.93 \pm 11.90$ & $213.80 \pm 49.97$ & $6.19 \pm 0.25$ & $6.18 \pm 0.86$ & $6.19 \pm 0.57 \mathrm{~b}$ & $293.00 \pm 63.72$ & $232.00 \pm 10.46$ \\
\hline Mean & $14.53 \pm 1.57 \mathrm{~A}^{*}$ & $12.62 \pm 0.51 \mathrm{~B}$ & $16.72 \pm 1.14$ & $16.63 \pm 0.95$ & $216.68 \pm 39.15 \mathrm{~A}$ & $180.85 \pm 35.80 \mathrm{~B}$ & $6.98 \pm 1.14$ & $6.62 \pm 0.94$ & & $269.21 \pm 43.81 \mathrm{~A}$ & $222.88 \pm 20.17 \mathrm{~B}$ \\
\hline$p$ value & \multicolumn{2}{|c|}{0.000} & \multicolumn{2}{|c|}{$>0.05$} & \multicolumn{2}{|c|}{0.028} & \multicolumn{3}{|c|}{0.001} & \multicolumn{2}{|c|}{0.003} \\
\hline
\end{tabular}

*Lowercase letters within a column indicate significant differences among the treatments. Uppercase letters in the rows indicate the significant differences between the seasons

Table 4. Quality parameters evaluated at harvest after hormone treatments in 'Sultani' grapes (mean $\pm S D$ )

\begin{tabular}{|c|c|c|c|c|c|c|c|c|c|}
\hline \multirow[b]{2}{*}{ Hormones } & \multicolumn{2}{|c|}{$\begin{array}{l}\text { Soluble solids } \\
\text { (Brix) }\end{array}$} & \multicolumn{2}{|c|}{$\begin{array}{l}\text { Total acidity } \\
\text { g }(100 \text { g FW })\end{array}$} & \multicolumn{2}{|c|}{ pH } & \multicolumn{3}{|c|}{$\begin{array}{l}\text { Maturity index } \\
\text { (SS/TA) }\end{array}$} \\
\hline & 2017 & 2018 & 2017 & 2018 & 2017 & 2018 & 2017 & 2018 & Mean \\
\hline $\begin{array}{c}\mathrm{GA}_{3} \\
(10-15-20 \mathrm{ppm})\end{array}$ & $18.63 \pm 0.55$ & $22.32 \pm 0.68$ & $6.64 \pm 0.28$ & $8.20 \pm 0.23$ & $4.02 \pm 0.02$ & $3.94 \pm 0.02$ & $28.31 \pm 1.42$ & $27.26 \pm 1.32$ & $27.69 \pm 1.31 \mathrm{ab}$ \\
\hline $\mathrm{Hbl} 4$ ppm & $20.20 \pm 0.92$ & $21.20 \pm 1.30$ & $5.81 \pm, 0.47$ & $7.13 \pm 0.05$ & $4.11 \pm 0.07$ & $3.98 \pm 0.01$ & $35.02 \pm 4.27$ & $29.71 \pm 1.64$ & $32.37 \pm 4.10 \mathrm{a}$ \\
\hline Hbl 8 ppm & $18.98 \pm 0.21$ & $21.03 \pm 1.72$ & $6.88 \pm 0.79$ & $7.80 \pm 0.27$ & $3.93 \pm 0.09$ & $3.97 \pm 0.04$ & $27.83 \pm 2.94$ & $26.97 \pm 2.37$ & $27.40 \pm 2.44 \mathrm{ab}$ \\
\hline Control & $17.90 \pm 1.72$ & $20.13 \pm 0.58$ & $7.07 \pm 1.24$ & $8.12 \pm 1.34$ & $4.02 \pm 0.13$ & $4.02 \pm 0.03$ & $26.12 \pm 6.52$ & $25.24 \pm 4.21$ & $25.68 \pm 4.93 \mathrm{~b}$ \\
\hline Mean & $18.94 \pm 1.22 \mathrm{~B} *$ & $21.18 \pm 1.29 \mathrm{~A}$ & $6.60 \pm 0.84 \mathrm{~B}$ & $7.82 \pm 0.74 \mathrm{~A}$ & $4.02 \pm 0.10$ & $3.98 \pm 0.04$ & $29.87 \pm 5.06$ & $27.30 \pm 2.80$ & \\
\hline$p$ value & \multicolumn{2}{|c|}{0.000} & \multicolumn{2}{|c|}{0.001} & \multicolumn{2}{|c|}{$>0.05$} & \multicolumn{3}{|c|}{0.027} \\
\hline
\end{tabular}

*Lowercase letters within a column indicate significant differences among the treatments. Uppercase letters in the rows indicate the significant differences between the seasons 
Table 5. Chromatic parameters of the 'Sultani' berries treated with hormones (mean $\pm S D$ )

\begin{tabular}{|c|c|c|c|c|c|c|c|c|}
\hline \multirow[b]{2}{*}{ Hormones } & \multicolumn{2}{|c|}{$L^{*}$} & \multicolumn{2}{|c|}{$a^{*}$} & \multicolumn{2}{|c|}{$b^{*}$} & \multicolumn{2}{|c|}{ CIRG (scale) } \\
\hline & 2017 & 2018 & 2017 & 2018 & 2017 & 2018 & 2017 & 2018 \\
\hline $\begin{array}{c}\mathrm{GA}_{3} \\
(10-15-20 \mathrm{ppm})\end{array}$ & $42.55 \pm 3.88 \mathrm{Bab}^{*}$ & $48.87 \pm 0.49 \mathrm{Aa}$ & $-7.29 \pm 0.33$ & $-8.67 \pm 1.12$ & $20.62 \pm 1.68 \mathrm{Aab}$ & $20.91 \pm 0.53 \mathrm{Aa}$ & $1.10 \pm 0.07$ & $0.94 \pm 0.04$ \\
\hline $\mathrm{Hbl} 4 \mathrm{ppm}$ & $44.03 \pm 3.4 \mathrm{Ba}$ & $48.94 \pm 0.61 \mathrm{Aa}$ & $-7.51 \pm 0.52$ & $-9.16 \pm 0.73$ & $20.76 \pm 1.21 \mathrm{Aa}$ & $21.48 \pm 0.48 \mathrm{Aa}$ & $1.06 \pm 0.06$ & $0.93 \pm 0.03$ \\
\hline Hbl 8 ppm & $42.08 \pm 2.32 \mathrm{Bab}$ & $50.98 \pm 1.92 \mathrm{Aa}$ & $-7.21 \pm 0.69$ & $-8.87 \pm 0.36$ & $20.37 \pm 1.16 \mathrm{Bab}$ & $25.12 \pm 3.31 \mathrm{Aa}$ & $1.11 \pm 0.05$ & $0.91 \pm 0.04$ \\
\hline Control & $34.59 \pm 7.55 \mathrm{Bb}$ & $51.12 \pm 2.19 \mathrm{Aa}$ & $-7.22 \pm 0.98$ & $-8.26 \pm 0.73$ & $16.32 \pm 0.76 \mathrm{Ab}$ & $24.04 \pm 2.53 \mathrm{Aa}$ & $1.29 \pm 0.22$ & $0.93 \pm 0.03$ \\
\hline Mean & $40.81 \pm 5.56$ & $49.98 \pm 1.71$ & $-7.31 \pm 0.59 \mathrm{~B}$ & $-8.74 \pm 0.75 \mathrm{~A}$ & $19.52 \pm 2.21$ & $22.89 \pm 2.56$ & $1.14 \pm 0.14 \mathrm{~A}$ & $0.93 \pm 0.03 \mathrm{~B}$ \\
\hline$p$ value & \multicolumn{2}{|c|}{0.049} & \multicolumn{2}{|c|}{0.000} & \multicolumn{2}{|c|}{0.005} & \multicolumn{2}{|c|}{0.000} \\
\hline
\end{tabular}

*Lowercase letters within a column indicate significant differences among the treatments. Uppercase letters in the rows indicate the significant differences between the seasons

Table 6. Total anthocyanin, total phenolics, fructose and glucose contents of 'Sultani' berries treated with hormones (mean $\pm S D)$

\begin{tabular}{|c|c|c|c|c|c|c|c|c|}
\hline \multirow[b]{2}{*}{ Hormones } & \multicolumn{3}{|c|}{$\begin{array}{c}\text { TAC } \\
(\mathrm{mg} / \mathbf{1 0 0} \mathrm{g} \mathrm{FW})\end{array}$} & \multicolumn{3}{|c|}{$\begin{array}{c}\text { Total phenolics } \\
\text { (mg GAE/100 g FW) }\end{array}$} & \multirow{2}{*}{$\begin{array}{c}\text { Fructose (\%) } \\
2017\end{array}$} & \multirow{2}{*}{$\begin{array}{c}\begin{array}{c}\text { Glucose } \\
(\%)\end{array} \\
2018 \\
\end{array}$} \\
\hline & 2017 & 2018 & Mean & 2017 & 2018 & Mean & & \\
\hline $\begin{array}{c}\mathrm{GA}_{3} \\
(10-15-20 \mathrm{ppm}) \\
\end{array}$ & $3.23 \pm 0.83$ & $6.08 \pm 0.93$ & $4.66 \pm 1.74 \mathrm{a}^{*}$ & $40.38 \pm 4.90$ & $76.51 \pm 6.0$ & $58.45 \pm 20.39 \mathrm{a}^{*}$ & $5.69 \pm 2.60 \mathrm{~b}$ & $5.06 \pm 0.13 \mathrm{a}$ \\
\hline $\mathrm{Hbl} 4 \mathrm{ppm}$ & $2.32 \pm 0.37$ & $5.86 \pm 0.92$ & $4.09 \pm 2.03 \mathrm{ab}$ & $34.64 \pm 10.11$ & $63.67 \pm 3.76$ & $49.16 \pm 17.30 \mathrm{~b}$ & $7.93 \pm 0.85 \mathrm{a}$ & $5.58 \pm 0.39 \mathrm{a}$ \\
\hline $\mathrm{Hbl} 8 \mathrm{ppm}$ & $2.37 \pm 0.22$ & $5.43 \pm 1.69$ & $3.90 \pm 1.69 \mathrm{ab}$ & $38.78 \pm 4.03$ & $61.89 \pm 1.21$ & $50.34 \pm 13.99 \mathrm{~b}$ & $6.60 \pm 0.33 \mathrm{ab}$ & $5.01 \pm 0.17 \mathrm{a}$ \\
\hline Control & $1.99 \pm 0.65$ & $4.46 \pm 0.57$ & $3.23 \pm 1.43 \mathrm{~b}$ & $28.23 \pm 5.00$ & $63.51 \pm 0.21$ & $55.87 \pm 19.60 \mathrm{ab}$ & $5.38 \pm 0.48 b$ & $4.33 \pm 0.03 \mathrm{~b}$ \\
\hline Mean & $2.48 \pm 0.66 \mathrm{~B}$ & $5.46 \pm 0.89 \mathrm{~A}$ & & $35.51 \pm 7.38 \mathrm{~B}$ & $66.40 \pm 7.77 \mathrm{~A}$ & & $6.40 \pm 1.14$ & $4.92 \pm 0.51$ \\
\hline$p$ value & \multicolumn{3}{|c|}{$\begin{array}{c}0.000 \text { (years) } \\
0.010 \text { (treatments) }\end{array}$} & \multicolumn{3}{|c|}{$\begin{array}{c}0.000 \text { (years) } \\
0.015 \text { (treatments) }\end{array}$} & 0.000 & 0.000 \\
\hline
\end{tabular}

*Lowercase letters within a column indicate significant differences among the treatments. Uppercase letters in the rows indicate the significant differences between the seasons 


\section{Conclusion}

No matter the information gathered from this study and from all previous conducted valuable studies indicate that hormones do not greatly influence fruit growth and quality, understanding the role of plant growth regulators in composing grape quality and improving yield still requires some researches. Despite its relatively new-found place among plant hormones, brassinosteroids do have some promising effects on quality and quantity, obviously depending on its type, concentration and the time of application. Due to their degradation and limited transport, it might be useful to apply at the closest time or phenological stage to the intended outcome and therefore, repeated applications may be more effective. Improvement shown by brassinosteroid applications in berry firmness, color development and anthocyanin increases validate these hormones to be the subject of further research.

Acknowledgment. The author thanks Dr. Bhushan Mandava and Prof. Dr. Zeliha Gökbayrak for kindly providing the 28-homobrassinolide.

\section{REFERENCES}

[1] Acheampong, A. K., Hu, J., Rotman, A., Zheng, C., Halaly, T., Takebayashi, Y., Jikumaru, Y., Kamiya, Y., Lichter, A., Sun, T. P., Or, E. (2015): Functional characterization and developmental expression profiling of gibberellin signaling components in Vitis vinifera. - Journal of Experimental Botany 66: 1463-1476. DOI: 10.1093/jxb/eru504.

[2] Ali, B. (2017): Practical applications of brassinosteroids in horticulture-some field perspectives. - Scientia Horticulturae 225: 15-21. DOI: 10.1016/j.scienta.2017.06.051.

[3] Asghari, M., Rezaei-Rad, R. (2018): 24-Epibrassinolide enhanced the quality parameters and phytochemical contents of table grape. - Journal of Applied Botany and Food Quality 91: 226-231. DOI: 10.5073/JABFQ.2018.091.030.

[4] Baneh, H. D., Jafari, H., Marandi, J., Abdolahi, R. (2017): Effect of pre-bloom gibberellic acid application on aeedlessness and some fruit traits of three Iranian seeded grape cultivars. - Majallah-i Ulum-i Bāghbānī 31(1): 110-121(12). DOI: 10.22067/jhorts4.v0i0.44918.

[5] Bartwal, A., Mall, R., Lohani, P., Guru, S. K., Arora, S. (2013): "Role of secondary metabolites and brassinosteroids in plant defense against environmental stresses". Journal of Plant Growth Regulation 32: 216-232. DOI: 10.1007/s00344-012-9272-x.

[6] Camara, M., Diez, C., Torija, M. E. (1996): Free sugars determination by HPLC in pineapple products. - Zeitschrift für Lebensmittel-Untersuchung und -Forschung 202: 233-237.

[7] Chai, Y. M., Zhang, Q., Tian, L., Li, C. L., Xing, Y., Q1n, L., et al. (2013): Carreño, J., Martinez, A., Almela, L., Fernadezlopez, J. A. (1996): Measuring the color of table grapes. - Color Research \& Application 21: 50-54. DOI: 10.1002/(SICI)15206378(199602)21:1<50::AID-COL5>3.0.CO;2-4.

[8] Chai, Y. M., Zhang, Q. (2012): Brassinosteroid is involved in strawberry fruit ripening. Plant Growth Regulator 69: 63-69.

[9] Champa, W., Gill, M., Mahajan, B. V. C., Aror, N. K., Bedi, S. (2015): Brassinosteroids improve quality of table grapes (Vitis vinifera L.) cv. Flame Seedless. - Tropical Agricultural Research 26: 368-379. DOI: 10.4038/tar.v26i2.8099. 
[10] Ghorbani, P., Eshghi, S., Haghi, H. (2017): Effects of brassinosteroid (24-epibrassinolide) on yield and quality of grape (Vitis vinifera L.) 'Thompson Seedless'. - Vitis 56: 113117. DOI: $10.5073 /$ vitis.2017.56.113-117.

[11] Haubrick, L. L., Assmann, S. M. (2006): Brassinosteroids and plant function: some clues, more puzzles. - Plant, Cell Environment 29: 446-457. DOI: 10.1111/j.13653040.2005.01481.x.

[12] İşçi, B., Altındişli, A. (2015): Drying of Vitis vinifera L. cv "Sultanina" in tunnel solar drier. - BIO Web of Conferences 5: 01016. DOI: 10.1051/bioconf/20150501016.

[13] İşçi, B., Gökbayrak, Z. (2015): Influence of brassinosteroids on fruit yield and quality of table grape 'Alphonse Lavallée'. - Vitis 54: 17-19.

[14] Koukourikou, M., Zioziou, E., Pantazaki, A., Nikolaos, Nikolaou, N., Kyriakidis, D. (2015): Effects of gibberellic acid and putrescine on 'Thompson Seedless' grapes. American International Journal of Biology 3: 19-29. DOI: 10.15640/aijb.v3n2a2.

[15] Ma, L. N., Xi, Z. M., GAO, X., Huo, S. S., Luan, L. Y. (2012): Effects of abscisic acid and 24 epibrassinolide on the endogenous contents of the plant hormone of berries in the process of grape ripening. - North Horticulture 17: 16-19.

[16] Mitchell, J. W., Mandava, N., Worley, J. F., Plimmer, J. R.. (1970): Brassins-a New family of plant hormones from rape pollen. - Nature 225: 1065-1066. DOI: $10.1038 / 2251065 \mathrm{a} 0$.

[17] Nicolaescu, G., Derendovskaia, A., Secrieru, S., Mihov, D., Procopenc, V., Godoroj, M., Lungu, C. (2015): The influence of treatment with growth stimulator (gobbi gib 2lg) on the quantity and quality of seedless grape 'Beauty Seedless'. - Agro Life Scientific Journal 4: 72-79.

[18] Peppi, M. C., Fidelibus, M. W. (2008): Effects of forchlorfenuron and abscisic acid on the quality of 'Flame Seedless' grapes. - HortScience 43: 173-176. DOI: 10.21273/HORTSCI.43.1.173.

[19] Que, F., Wang, G. L., Xu, Z. S., Wang, F., Xiong, A. S. (2017): Transcriptional regulation of brassinosteroid accumulation during carrot development and the potential role of brassinosteroids in petiole elongation. - Front Plant Science 8: 1356. https://doi.org/10.3389/fpls.2017.01356.

[20] Reynolds, A., Robbins, N., Lee, H. S., Kotsaki, E. (2016): Impacts and interactions of abscisic acid and gibberellic acid on sovereign coronation and Skookum Seedless Table Grapes. - American Journal of Enology and Viticulture 67: 327-338. DOI: 10.5344/ajev.2016.15108.

[21] Senthilkumar, S., Vijayakumar, R. M., Soorianathasundaram, K., Devi, D. D. (2018): Impact of pre-harvest sprays with gibberellic acid on yield and economics of grape (Vitis vinifera L.) cv. Italia. -Annals of Biology 34: 170-175.

[22] Suehiro, Y., Mochida, K., Tsuma, M., Yasuda, Y., Hiroyuki, Itamura, H., Esumi, T. (2018): Effects of gibberellic acid/cytokinin treatments on berry development and maturation in the yellow-green skinned 'Shine Muscat' grape. - Japanese Society for Horticultural Science 1-12. DOI: 10.2503/hortj.UTD-046.

[23] Symons, G. M., Davies, C., Shavrukov, Y., Dry, I. B., Reid, J. B., Thomas, M. R. (2006): Grapes on steroids: brassinosteroids are involved in grape berry ripening. - Plant Physiol. 140: 150-158. DOI: 10.1104/pp.105.070706.

[24] Thaiponga, K., Boonprakoba, U., Crosbyb, K., Cisneros, Z. L., Hawkins, B. D. (2006): Comparison of ABTS, DPPH, FRAP, and ORAC assays for estimating antioxidant activity from guava fruit extracts. - Journal of Food Composition and Analysis 19: 669675. DOI: 10.1016/j.jfca.2006.01.003.

[25] Vardhini, B. V., Ram, Rao, S. S. (2002): Acceleration of ripening of tomato pericarp discs by brassinosteroids. - Phytochem 61: 843-847. DOI: 10.1016/500319422(02)00223-6.

[26] Vergara, A. E., Díaz, K., Carvajal, R., Espinoza, L., Alcalde, J. A., Pérez-Donoso, A. G. (2018): Exogenous applications of brassinosteroids improve color of red table grape 
(Vitis vinifera L. Cv. "Redglobe") berries. - Frontiers in Plant Science 9: 363-374. DOI: 10.3389/fpls.2018.00363.

[27] Villarreal, N. M., Rosli, H. G., Martínez, G. A., Civello, P. M. (2008): Polygalacturonase activity and expression of related genes during ripening of strawberry cultivars with contrasting fruit firmness. - Postharvest Biology and Technology 47: 141-150.

[28] Xi, Z., Zhang, Z., Huo, S., Luan, L., Gao, X. M. L., Fang, Y. (2013): Regulating the secondary metabolism in grape berry using exogenous 24-epibrassinolide for enhanced phenolics content and antioxidant capacity. - Food Chemistry 141: 3056-3065.

[29] Zoffoli, J. P., Latorre, B. A., Naranjo, P. (2009): Preharvest applications of growth regulators and their effect on postharvest quality of table grapes during cold storage. Postharvest Biology and Technology 51: 183-192. DOI: 10.1016/j.postharvbio.2008.06.013. 